\title{
Adaptive protection against damage of preconditioning human umbilical cord-derived mesenchymal stem cells with hydrogen peroxide
}

\author{
D. Li, Y. Xu, C.Y. Gao and Y.P. Zhai \\ Department of Cardiology, \\ The Henan Provincial People's Hospital of Zhengzhou University, China \\ Corresponding author: Y. Xu \\ E-mail: xuyucn@163.com
}

Genet. Mol. Res. 13 (3): 7304-7317 (2014)

Received May 24, 2013

Accepted October 3, 2013

Published February 21, 2014

DOI http://dx.doi.org/10.4238/2014.February.21.9

\begin{abstract}
Adaptive protection against damage to human umbilical cord-derived mesenchymal stem cells (hUC-MSCs) was investigated by preconditioning with low-concentration hydrogen peroxide $\left(\mathrm{H}_{2} \mathrm{O}_{2}\right)$ for a short-time period. Separation, culture, amplification, purification, and identification of immunophenotype and growth curve measurements of hUC-MSCs were performed in vitro. At the logarithmic phase, hUCMSCs were incubated with different $\mathrm{H}_{2} \mathrm{O}_{2}$ concentrations for 1 and 12 $\mathrm{h}$, and the effects were detected by a cell metabolism assay. Then, hUCMSCs were preconditioned with $10,20,50$, and $100 \mathrm{mM} \mathrm{H}_{2} \mathrm{O}_{2}$ for $1 \mathrm{~h}$, restored for 0,12 , and $24 \mathrm{~h}$, and then damaged with 700,800 , and 900 $\mathrm{mM} \mathrm{H}_{2} \mathrm{O}_{2}$ for $12 \mathrm{~h}$. Cell morphology, cell metabolism, and the number of cells were measured to determine the protective role of preconditioning. Flow cytometry analysis revealed that the cells expressed CD29 and CD44, but not CD34 and CD45. The growth curve showed that hUCMSCs reached the logarithmic phase in 3-6 days. The cell metabolism assay showed that $\mathrm{H}_{2} \mathrm{O}_{2}$ induced hUC-MSCs damage in a dose- and time-dependent manner. The cell morphology, cell metabolism, and number of cells all showed that preconditioning with 10,20,50, and 100
\end{abstract}


$\mathrm{mM} \mathrm{H}_{2} \mathrm{O}_{2}$ for $1 \mathrm{~h}$ and restoration for $12 \mathrm{~h}$ prevented subsequent damage with 700,800 , and $900 \mathrm{mM} \mathrm{H} \mathrm{O}_{2}$ on hUC-MSCs. Preconditioning with low-concentration $\mathrm{H}_{2} \mathrm{O}_{2}$ for a short time has a protective effect of preventing damage on hUC-MSCs exposed to high-concentration $\mathrm{H}_{2} \mathrm{O}_{2}$ for a long time, which is dependent on $\mathrm{H}_{2} \mathrm{O}_{2}$ concentration and the time interval between preconditioning and damage.

Key words: Hydrogen peroxide; Damage; Adaptive protection; hUC-MSCs; Preconditioning

\section{INTRODUCTION}

Human umbilical cord-derived mesenchymal stem cells (hUC-MSCs) are mesenchymal stem cells that are present in human umbilical connective tissue, and can differentiate into various types of cells. The cells can easily acquire harmless proliferation of both fast and slow immunogenicity, and they are therefore currently considered as ideal seed cells for treating cell damage or loss due to certain diseases, especially in the treatment of cardiovascular disease (Fong et al., 2010; Taghizadeh et al., 2011). However, the symptoms of ischemia, hypoxia, and inflammatory cell invasion in damaged zones result in oxidative stress and damage to mesenchymal stem cell activity, which limit their applications (Toma et al., 2002). Li et al. (2009) found that low-concentration hydrogen peroxide $\left(\mathrm{H}_{2} \mathrm{O}_{2}\right)$ pretreatment on bone marrow mesenchymal stem cells had an adaptive protective effect against oxidative stress; however, studies reporting such effects on hUC-MSCs are rare. In the present study, the effects of different concentrations and reaction times of $\mathrm{H}_{2} \mathrm{O}_{2}$ on hUC-MSC activity were evaluated. The pretreatment of $\mathrm{H}_{2} \mathrm{O}_{2}$ on the protection of hUC-MSCs and its mechanisms will provide a theoretical basis for optimizing hUC-MSC transplantation.

\section{MATERIAL AND METHODS}

\section{Main reagents}

The following reagents were used in the experiments: Dulbecco's modified Eagle's medium (DMEM)/F12 (Gibco, USA), fetal bovine serum (Gibco), penicillin and streptomycin (Solarbio), 0.02\% ethylenediaminetetraacetic acid (EDTA) and trypsin (Solarbio), four methyl thiazolyl tetrazolium (MTT) (Amresco Inc., USA), dimethyl sulfoxide (DMSO) (Amresco Inc.), trypan blue (Sigma), phycoerythrin (PE)-CD29 antibody, allophycocyanin (APC)-CD44 antibody, fluorescein isothiocyanate (FITC)-CD34 antibody, and peredinin chlorophyll protein (PerCP)-CD45 antibody (eBioscience Company, USA), and $\mathrm{H}_{2} \mathrm{O}_{2}$ (China National Pharmaceutical Group Co., Ltd.).

\section{Separation, cultivation, amplification, and purification of hUC-MSCs}

The discarded umbilical cord tissue of full-term cesarean section healthy fetuses were collected from the operating table (according to the regulations of the hospital and with consent of the family members), and immediately soaked in saline. The umbilical cords were moved to 
a clean bench, clipped to approximately $7-8 \mathrm{~cm}$, and residual blood was washed off thoroughly with saline, excluding the inner and outer membranes of vascular tissue (umbilical artery and umbilical vein). The cells were isolated from the Wharton's jelly, which was stripped off and cut into $1-\mathrm{mm}^{3}$ pieces. The collected tissue blocks were then added to saline and centrifuged for $3 \mathrm{~min}$ at $1200 \mathrm{rpm}$, the supernatant was removed, and the organization blocks were inoculated on Petri dishes containing DMEM/F12 complete medium with a straw, cultivated in a $37^{\circ} \mathrm{C}$ and $5 \% \mathrm{CO}_{2}$ humidity-saturated incubator, and cell growth was observed under an inverted microscope. The medium was first changed after 5-6 days and then every 3 days thereafter. The tissue block was removed once cells grew to complete fusion, and the cells were digested with $0.02 \%$ EDTA trypsin, passaged at a 1:2-1:3 amplified culture ratio, and purified.

\section{hUC-MSC phenotype determination}

P4 cells were collected, digested into a single-cell suspension, centrifuged for $5 \mathrm{~min}$ at $1200 \mathrm{rpm}$, and the cell pellet was washed with phosphate-buffered saline 3 times. The cell concentration was then adjusted to $1.0 \times 10^{6} \mathrm{cells} / \mathrm{mL}$ per each $50-60 \mu \mathrm{L}$ tube, according to the number of cells. To each tube, 20- $\mu \mathrm{L}$ saturation concentration PE-, APC-, FITC-, or PerCPlabeled mouse anti-human antibody CD29, CD44, CD34, or CD45, respectively, were added; the negative control tube was incubated in the same manner, but the homotype antibody was fluorescently labeled instead. Cells were incubated at room temperature for $30 \mathrm{~min}$, washed away from any unbound antibody, and 50,000-100,000 cell-surfaced antigen was expressed by flow cytometry.

\section{hUC-MSC growth curve test}

The number of cells in the $\mathrm{P} 4$ generation was counted after digestion and adjusted to a $1 \times 10^{4}$ cells $/ \mathrm{mL}$ concentration. A $200-\mu \mathrm{L}$ cell suspension was inoculated on a 96 -well cell culture plate, with five sets of wells for all 8 groups, and placed into a $37^{\circ} \mathrm{C}, 5 \% \mathrm{CO}_{2}$ humidity-saturated incubator. After $12 \mathrm{~h}, 20 \mu \mathrm{L} 0.5 \%$ MTT was added to the first set of wells in the dark and sterile-cultured for $4 \mathrm{~h}$. The medium and MTT mixture was then sucked out from inside the well, and $150 \mu \mathrm{L}$ DMSO was added to each well, oscillating at low speed for 10 min on a shaking table. Absorbance values (optical density, OD) of cells at each well were measured at $540 \mathrm{~nm}$ in the enzyme-linked immunosorbent assay (ELISA), in which the cellfree medium was used as the zero blank well. The above steps were repeated every $24 \mathrm{~h}$ for 8 days of continuous measurement. The final results, including the number of days (x-axis) and absorbance value (y-axis), were used to construct the cell growth curve. The experiment was repeated three times.

\section{Experimental groups}

\section{Establishment of oxidative stress-simulated conditions}

To simulate oxidative stress, $30 \% \mathrm{H}_{2} \mathrm{O}_{2}$ dissolved in complete medium were prepared into final concentrations of 1000, 900, 800, 700, 600, 500, 400, 300, 200, 100, 50, 20, and 10 $\mathrm{mM}$ media; the control group consisted of $\mathrm{H}_{2} \mathrm{O}_{2}$-free DMEM/F12 complete medium. 


\section{Establishment of hUC-MSCs from the oxidative stress preconditioning and injury programs}

After digesting and counting cells of the $\mathrm{P} 4$ generation, the cell concentration was adjusted to $1 \times 10^{4}$ cells $/ \mathrm{mL}$, and $200-\mu \mathrm{L}$ cell suspension was inoculated into each well of a 96well culture plate and cultivated in a $37^{\circ} \mathrm{C} 5 \% \mathrm{CO}_{2}$ humidified incubator. Once the cells grew to the logarithmic phase, they were divided into two groups: the first group was cultured using the $\mathrm{H}_{2} \mathrm{O}_{2}$ concentrations listed above in conditioned medium for $1 \mathrm{~h}$, and the control group was cultured in $\mathrm{H}_{2} \mathrm{O}_{2}$-free DMEM/F12 complete medium. Cells were then given a recovery period in complete medium, and a second round of culturing was performed as described above for 12 after $24 \mathrm{~h}$. Subsequently, both groups were placed in the dark together, $20 \mu \mathrm{L} 0.5 \%$ MTT was added, cells were sterile-cultured for $4 \mathrm{~h}$ to absorb the mixture of medium and MTT, and then $150 \mu \mathrm{L}$ DMSO was added oscillating at low speed on a shaker table for $10 \mathrm{~min}$. Absorbance values (OD) of cells from each well were measured at $540 \mathrm{~nm}$ in the ELISA, and the cell-free culture medium was used as the zero blank. The experiment was repeated three times.

\section{Adaptive protection of oxidative stress preconditioning to hUC-MSC damage}

After digesting and counting cells of the $\mathrm{P} 4$ generation, the cell concentration was adjusted to $1 \times 10^{4}$ cells $/ \mathrm{mL}$, and $200-\mu \mathrm{L}$ cell suspension was inoculated into each well of a 96-well cell culture plate and cultivated in a $37^{\circ} \mathrm{C} 5 \% \mathrm{CO}_{2}$ humidified incubator. Once the cells grew to the logarithmic phase, the preconditioned group's medium was replaced with 10, 20, 50 , and $100 \mathrm{mM} \mathrm{H}_{2} \mathrm{O}_{2}$-conditioned medium for $1 \mathrm{~h}$, whereas the no pretreatment group was cultured with $\mathrm{H}_{2} \mathrm{O}_{2}$-free DMEM/F12 complete medium for $1 \mathrm{~h}$. Subsequently, all media were replaced with $\mathrm{H}_{2} \mathrm{O}_{2}$-free complete medium for 0,12 , or $24 \mathrm{~h}$, and then the media of the damage group was replaced with 700,800 , or $900 \mathrm{mM} \mathrm{H}_{2} \mathrm{O}_{2}$-conditioned medium for $12 \mathrm{~h}$, whereas the control group was again cultured with $\mathrm{H}_{2} \mathrm{O}_{2}$-free DMEM/F12 complete medium for $12 \mathrm{~h}$.

\section{Microscope photography}

After the above treatments, the cell damage condition was assessed by inverted micrography.

\section{MTT assay of metabolic rate}

After the above treatments, $20 \mu \mathrm{L} 0.5 \%$ MTT was added to each well in the dark, cells were sterile-cultured for $4 \mathrm{~h}$ to absorb the mixture of medium and MTT, $150 \mu \mathrm{L}$ DMSO was added, and the mixtures were oscillated at low speed on a shaking table for $10 \mathrm{~min}$. Absorbance values (OD) were measured in each well at $540 \mathrm{~nm}$ in the ELISA, using cell-free culture medium as the zero blank.

\section{Trypan blue counting to detect cell activity}

After the treatments described above, the cell surfaces were covered with $0.02 \%$ EDTA trypsin for digestion, neutralized with serum-containing complete medium, and adherent cells 
were repeatedly gently pipetted to establish single cell suspensions. Trypan blue mother liquor was diluted to $0.4 \%$, and mixed with the cell suspension at a 9:1 ratio. The number of viable cells in each group was counted using a hematocytometer.

\section{Statistical analysis}

Measurement data are reported as means \pm standard deviation, and data among groups were compared using one-way analysis of variance (ANOVA). $\mathrm{P}<0.05$ was considered to be statistically significant, and all analyses were conducted with the SPSS 17.0 statistical software.

\section{RESULTS}

\section{Separation, cultivation, amplification, and purification of hUC-MSCs}

Cells bled out from umbilical cord tissue blocks, and dispersed and adhered 5 days later. The adhering cells were double-protuberant fusiformis or tabular polygonal in appearance with good diopter and evident nuclei (Figure 1A). After 13 days of development, the cellular form became homogeneous, appeared as vimineous fusiformis, and the cellular colony could mix homogenously (Figure 1B). After passage, the rate of cellular growth increased, and passaged every 4-5 days thereafter. At low concentrations, cells grew as an oblate monolayer (Figure 1C), or as vimineous under high cellular density and attending mix, in a manner similar to desmocytes. Cells showed parallel growth arrangement or gyrate growth (Figure 1D). In generations 1-10, the cells did not show any obvious change in form. However, after 15 generations, the speed of proliferation reduced, and the cell size increased (Figure 1).

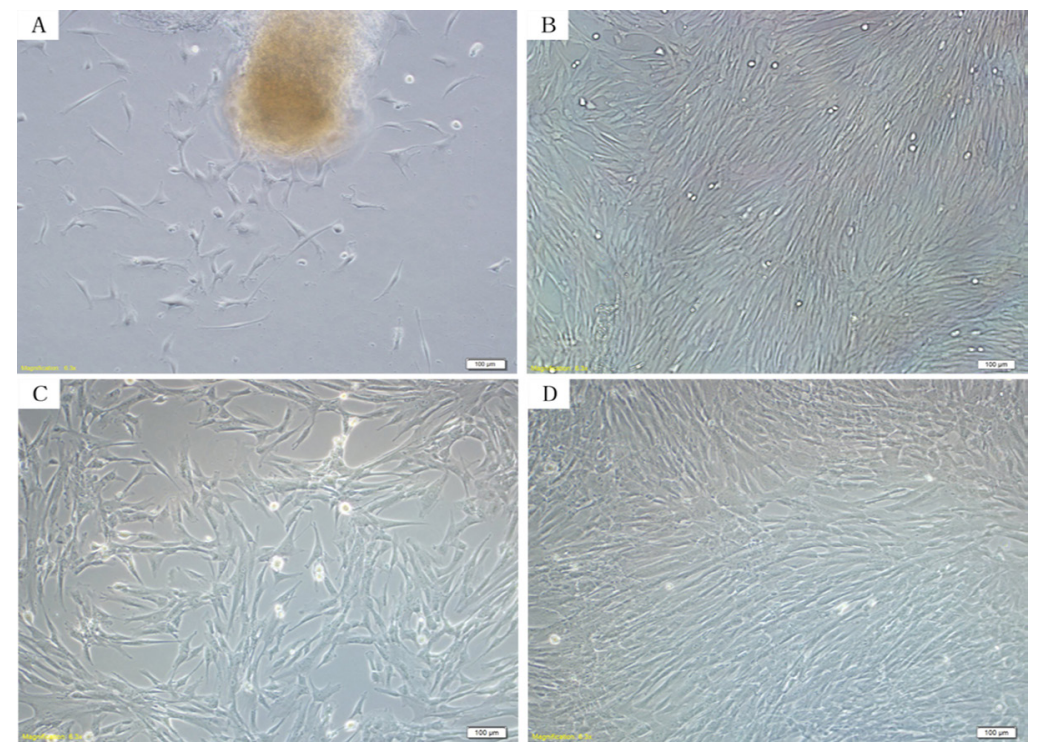

Figure 1. Human umbilical cord mesenchymal stem cell. A. B. Human umbilical cord mesenchymal stem cell by tissue adherent method after 5 and 13 days; C. D. Four generations of human umbilical cord mesenchymal stem cell with different concentrations. 


\section{hUC-MSC phenotype determination}

The flow detection method was used to detect the cultured P4 generation cell surface antigen markers, and the results were uniform and stable, demonstrating high expression of the hUC-MSC-specific markers CD29 and CD44, and almost no expression of the hematopoietic stem cell-specific markers CD34 and CD45 (Figure 2).
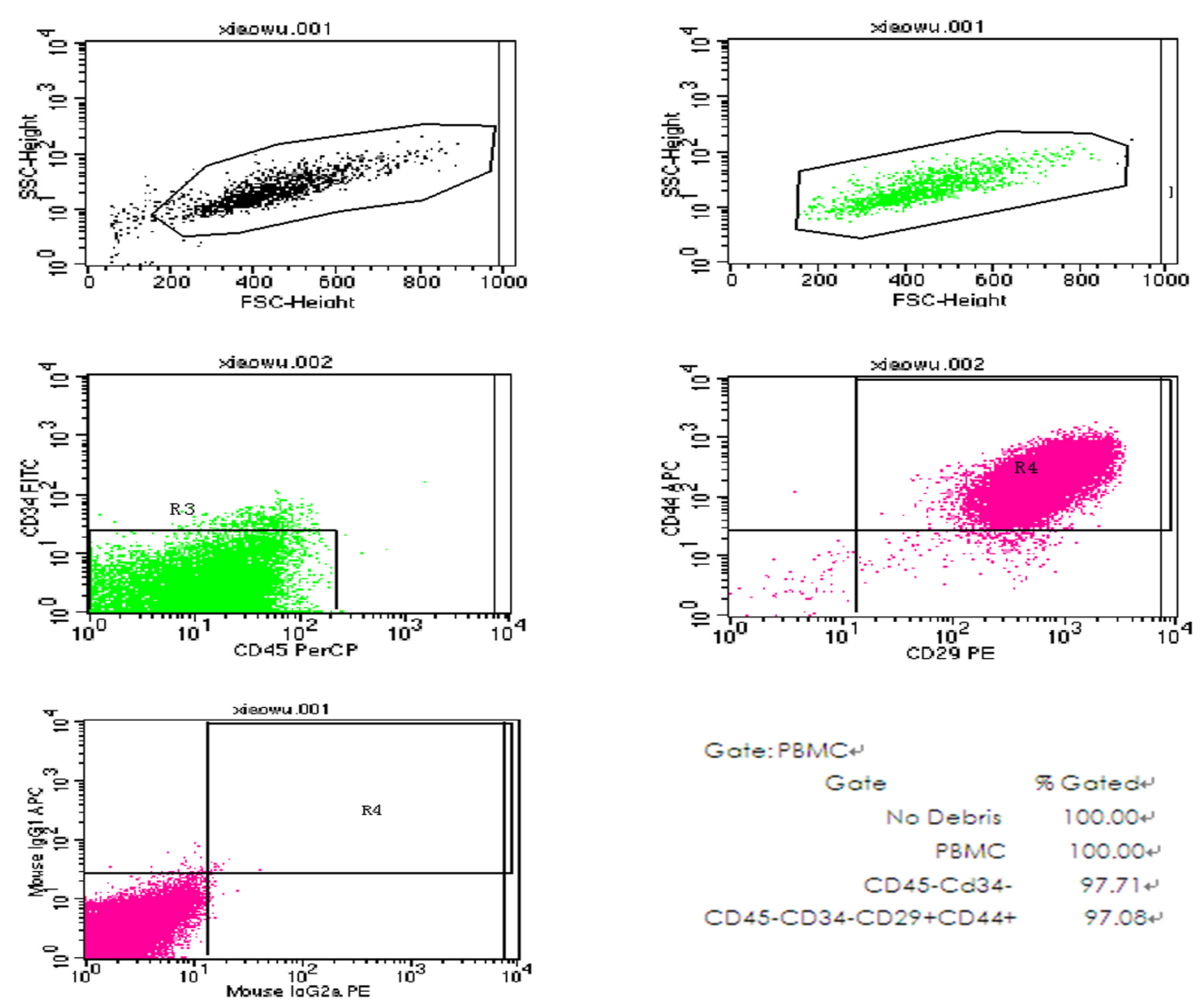

Figure 2. Immune phenotype of human umbilical cord mesenchymal stem cells by flow cytometry.

\section{hUC-MSC growth curve test}

When cultivating P4 generation cells, microscopy observations showed that cells were more or less adherent. The cellular metabolic rate was measured in the incubation period on the 1 st and 2 nd days when there was no significant growth and proliferation phenomena. On the 3 rd to the 6 th days, cells entered the logarithmic growth phase, at which point they significantly proliferated and grew rapidly. After 6-7 days, the cells entered the platform period, and the cell doubling time was 3-4 days (Figure 3). 


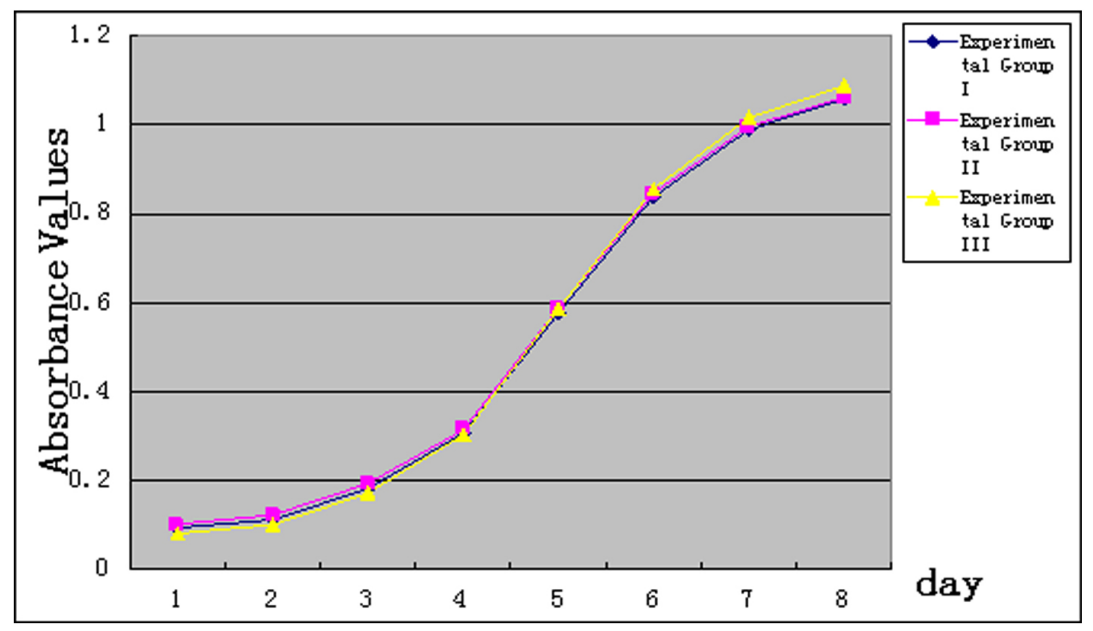

Figure 3. Growth curve of human umbilical cord mesenchymal stem cell.

\section{Establishment of the oxidative stress preconditioning and injury program to hUC-MSCs}

The activity of $\mathrm{P} 4$ generation cells gradually reduced with increasing $\mathrm{H}_{2} \mathrm{O}_{2}$ concentration and duration of action. The group that was incubated with $10-100 \mathrm{mM} \mathrm{H}_{2} \mathrm{O}_{2}$ for $1 \mathrm{~h}$ showed no difference in cell activity compared to the control group $(\mathrm{P}>0.05)$. However, the activity of the group exposed to $100-1000 \mathrm{mM} \mathrm{H}_{2} \mathrm{O}_{2}$ was significantly lower than that of the control group $(\mathrm{P}<0.05)$, as shown in Table 1. The group exposed to $10-50 \mathrm{mM} \mathrm{H}_{2} \mathrm{O}_{2}$ for 12 $\mathrm{h}$ showed no significant difference in cell activity compared to the control group ( $\mathrm{P}>0.05)$, whereas the activity of the $50-1000 \mathrm{mM} \mathrm{H}_{2} \mathrm{O}_{2}$ group for $12 \mathrm{~h}$ was significantly lower than that of the control group $(\mathrm{P}<0.05)$, as shown in Table 2. Cells could be preconditioned with 10 , 20, 50, and $100 \mathrm{mM} \mathrm{H}_{2} \mathrm{O}_{2}$ within $1 \mathrm{~h}$ and damaged with 700, 800, and $900 \mathrm{mM} \mathrm{H}_{2} \mathrm{O}_{2}$ in $12 \mathrm{~h}$.

\section{Adaptive protection of oxidative stress preconditioning against damage to hUC-MSCs}

Microscope observations showed that there were no significant differences between the precondition group and the control group in the number of cells; cells of both groups showed a long fusiform and closely arranged shape, and displayed parallel or swirl-like growth patterns (Figure 4A and B). The damage group had a significantly reduced number of cells compared to the control group, the cells morphologically changed to a rounded shape without the typical long spindle, and these cells were sparsely arranged and displayed no parallel or swirl-like growth patterns (Figure 4C). The group that was preconditioned for $1 \mathrm{~h}$ and allowed to recover for $12 \mathrm{~h}$ before damage had a significantly increased number of cells compared to the damage group; cells maintained their long, fusiform, closely arranged shape, displayed parallel or swirl-like growth patterns, and some apoptotic cells could be observed scattered throughout (Figure 4D). There were no significant differences between the group preconditioned for $1 \mathrm{~h}$ with recovery for 0 or $24 \mathrm{~h}$ before damage and the damage group with respect to the number of cells; both groups changed to a rounded shape without typical long spindles, and cells were sparsely arranged and displayed no parallel or swirl-like growth patterns. 


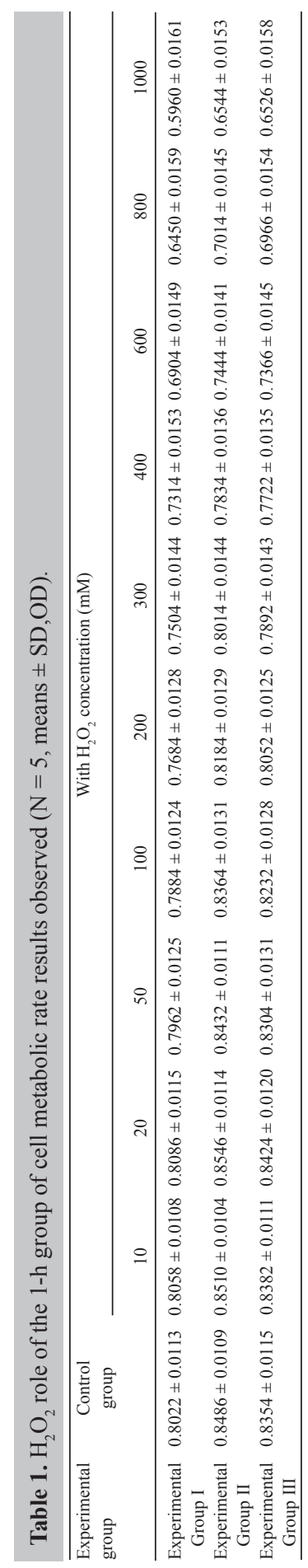




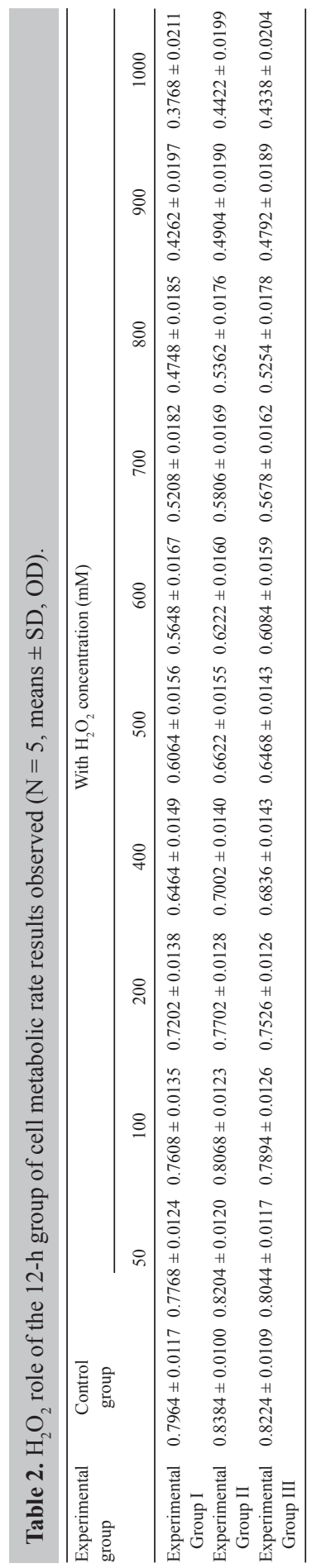



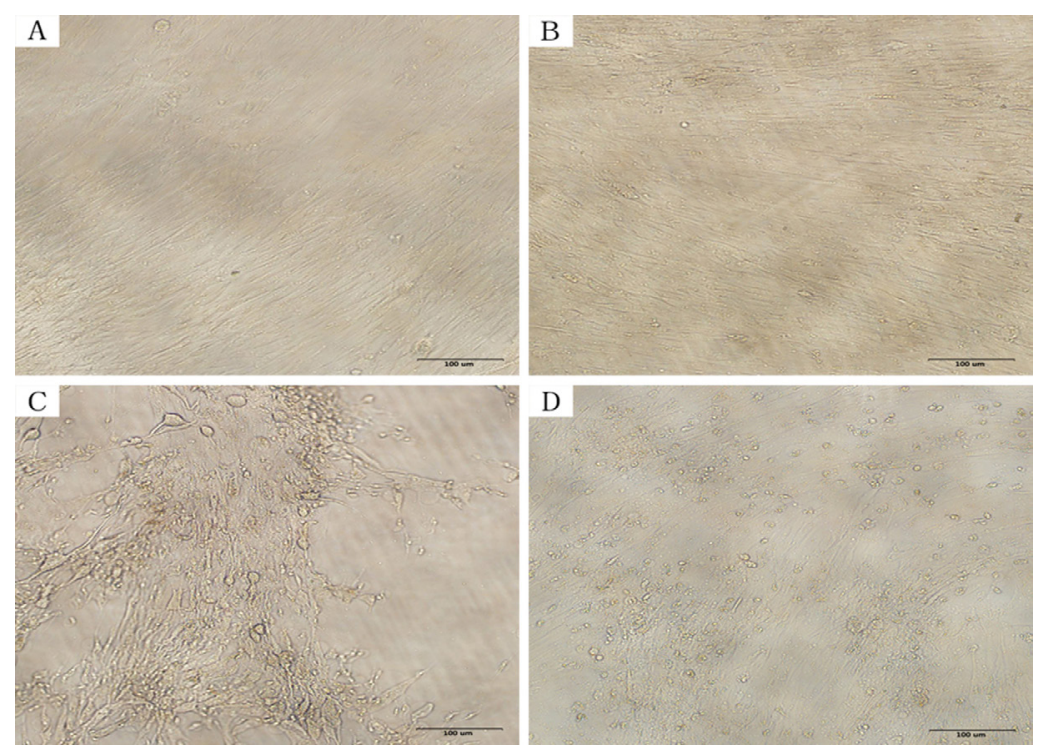

Figure 4. Adaptive protection of oxidative stress precondition to human umbilical cord mesenchymal stem cell against damage. A. Control group without $\mathrm{H}_{2} \mathrm{O}_{2}$ precondition; B. control group with $100 \mathrm{mM} \mathrm{H}_{2} \mathrm{O}_{2}$ precondition; C. injury group without $\mathrm{H}_{2} \mathrm{O}_{2}$ precondition; D. injury group with $100 \mathrm{mM} \mathrm{H}_{2} \mathrm{O}_{2}$ precondition.

The rate of cell metabolism did not differ significantly between the preconditioned groups and the control group $(\mathrm{P}>0.05)$; however, the damage group had a reduced cellular metabolic rate compared to the control group, and the difference was statistically significant ( $\mathrm{P}$ $<0.05$ ). The group with preconditioning for $1 \mathrm{~h}$ and recovery for $12 \mathrm{~h}$ before damage showed a significantly increased cellular metabolic rate compared to the damage group $(\mathrm{P}<0.05)$. The metabolic rates of groups preconditioned with 20,50, and $100 \mathrm{mM} \mathrm{H}_{2} \mathrm{O}_{2}$ showed obvious and significant differences ( $\mathrm{P}<0.01$; Table 3$)$. There were no significant differences in cellular metabolic rate observed between the groups preconditioned with 10-20 $\mathrm{mM} \mathrm{H}_{2} \mathrm{O}_{2}$ for $1 \mathrm{~h}$ with recovery for $24 \mathrm{~h}$ before damage and the damage group $(\mathrm{P}>0.05)$. Groups preconditioned with 50 and $100 \mathrm{mM} \mathrm{H}_{2} \mathrm{O}_{2}$ for $1 \mathrm{~h}$ with recovery for $24 \mathrm{~h}$ before damage showed significantly increased cellular metabolic rates compared to the damage group $(\mathrm{P}<0.05)$, and the group preconditioned with $100 \mathrm{mM} \mathrm{H}_{2} \mathrm{O}_{2}$ showed an obvious and significant increase $(\mathrm{P}<0.01$; Table 4). There were no significant differences in cellular metabolic rate between the group preconditioned for $1 \mathrm{~h}$ with recovery for $0 \mathrm{~h}$ before damage and the damage group $(\mathrm{P}>0.05)$, as shown in Table 5 .

Table 3. Cell metabolic rate results observed of $\mathrm{H}_{2} \mathrm{O}_{2}$ precondition and recovery for the 12 -h group $(\mathrm{N}=5$, means \pm $\mathrm{SD}, \mathrm{OD})$.

\begin{tabular}{lcccr}
\hline Groups & Control group & \multicolumn{3}{c}{ Concentration of $\mathrm{H}_{2} \mathrm{O}_{2}$ injury } \\
\cline { 3 - 5 } & & $700 \mathrm{mM}$ & $800 \mathrm{mM}$ & $900 \mathrm{mM}$ \\
\hline Without $\mathrm{H}_{2} \mathrm{O}_{2}$ precondition group & $0.7382 \pm 0.0124$ & $0.4384 \pm 0.0177$ & $0.3942 \pm 0.0192$ & $0.3484 \pm 0.0202$ \\
$10 \mathrm{mM}$ precondition group & $0.7410 \pm 0.0128$ & $0.4652 \pm 0.0168$ & $0.4214 \pm 0.0188$ & $0.3752 \pm 0.0191$ \\
$20 \mathrm{mM}$ precondition group & $0.7452 \pm 0.0127$ & $0.4944 \pm 0.0168$ & $0.4496 \pm 0.0170$ & $0.4028 \pm 0.0182$ \\
$50 \mathrm{mM}$ precondition group & $0.7332 \pm 0.0123$ & $0.5446 \pm 0.0162$ & $0.4984 \pm 0.0166$ & $0.4506 \pm 0.0180$ \\
$100 \mathrm{mM}$ precondition group & $0.7260 \pm 0.0135$ & $0.5846 \pm 0.0140$ & $0.5370 \pm 0.0155$ & $0.4882 \pm 0.0167$ \\
\hline
\end{tabular}




\begin{tabular}{|c|c|c|c|c|}
\hline \multirow[t]{2}{*}{ Groups } & \multirow[t]{2}{*}{ Control group } & \multicolumn{3}{|c|}{ Concentration of $\mathrm{H}_{2} \mathrm{O}_{2}$ injury } \\
\hline & & $700 \mathrm{mM}$ & $800 \mathrm{mM}$ & $900 \mathrm{mM}$ \\
\hline Without $\mathrm{H}_{2} \mathrm{O}_{2}$ precondition group & $0.8334 \pm 0.0115$ & $0.5112 \pm 0.0172$ & $0.4630 \pm 0.0177$ & $0.4132 \pm 0.0205$ \\
\hline $10 \mathrm{mM}$ precondition group & $0.8366 \pm 0.0106$ & $0.5184 \pm 0.0164$ & $0.4702 \pm 0.0174$ & $0.4204 \pm 0.0188$ \\
\hline $20 \mathrm{mM}$ precondition group & $0.8394 \pm 0.0117$ & $0.5250 \pm 0.0166$ & $0.4776 \pm 0.0178$ & $0.4270 \pm 0.0185$ \\
\hline $50 \mathrm{mM}$ precondition group & $0.8274 \pm 0.0109$ & $0.5404 \pm 0.0156$ & $0.4922 \pm 0.0171$ & $0.4424 \pm 0.0181$ \\
\hline $100 \mathrm{mM}$ precondition group & $0.8196 \pm 0.0119$ & $0.5534 \pm 0.0160$ & $0.5042 \pm 0.0164$ & $0.4538 \pm 0.0179$ \\
\hline
\end{tabular}

\begin{tabular}{|c|c|c|c|c|}
\hline \multirow[t]{2}{*}{ Groups } & \multirow[t]{2}{*}{ Control group } & \multicolumn{3}{|c|}{ Concentration of $\mathrm{H}_{2} \mathrm{O}_{2}$ injury } \\
\hline & & $700 \mathrm{mM}$ & $800 \mathrm{mM}$ & $900 \mathrm{mM}$ \\
\hline Without $\mathrm{H}_{2} \mathrm{O}_{2}$ precondition group & $0.5878 \pm 0.0138$ & $0.2668 \pm 0.0205$ & $0.2182 \pm 0.0202$ & $0.1684 \pm 0.0217$ \\
\hline $10 \mathrm{mM}$ precondition group & $0.5906 \pm 0.0144$ & $0.2626 \pm 0.0202$ & $0.2148 \pm 0.0213$ & $0.1642 \pm 0.0224$ \\
\hline $20 \mathrm{mM}$ precondition group & $0.5938 \pm 0.0140$ & $0.2584 \pm 0.0206$ & $0.2102 \pm 0.0207$ & $0.1600 \pm 0.0218$ \\
\hline $50 \mathrm{mM}$ precondition group & $0.5818 \pm 0.0143$ & $0.2512 \pm 0.0197$ & $0.2030 \pm 0.0213$ & $0.1534 \pm 0.0230$ \\
\hline $100 \mathrm{mM}$ precondition group & $0.5736 \pm 0.0149$ & $0.2404 \pm 0.0215$ & $0.1912 \pm 0.0218$ & $0.1404 \pm 0.0220$ \\
\hline
\end{tabular}

There were no significant differences in the number of cells between the preconditioned groups and control groups $(\mathrm{P}>0.05)$, whereas the damage group had a significantly reduced number of cells compared to the control group $(\mathrm{P}<0.05)$. There were no significant differences in cell number between the group preconditioned with $10 \mathrm{mM} \mathrm{H}_{2} \mathrm{O}_{2}$ for $1 \mathrm{~h}$ with recovery for $12 \mathrm{~h}$ before damage and the damage group $(\mathrm{P}>0.05)$, whereas the groups preconditioned with 20,50 , and $100 \mathrm{mM} \mathrm{H}_{2} \mathrm{O}_{2}$ for $1 \mathrm{~h}$ with recovery for $12 \mathrm{~h}$ before damage had a significantly increased number of cells compared to the damage groups $(\mathrm{P}<0.05)$. In addition, the groups preconditioned with 50 and $100 \mathrm{mM} \mathrm{H}_{2} \mathrm{O}_{2}$ showed an obvious and significant difference in cell number $(\mathrm{P}<0.01$; Table 6$)$. There were no significant differences in cell numbers between the groups preconditioned with 10,20 , and $50 \mathrm{mM} \mathrm{H}_{2} \mathrm{O}_{2}$ for $1 \mathrm{~h}$ with recovery for $24 \mathrm{~h}$ and the damage group $(\mathrm{P}>0.05)$, whereas the group preconditioned with $100 \mathrm{mM}$ $\mathrm{H}_{2} \mathrm{O}_{2}$ for $1 \mathrm{~h}$ with recovery for $24 \mathrm{~h}$ before damage had a significantly increased number of cells compared to the damage group $(\mathrm{P}<0.05$; Table 7). There were no significant differences in cell numbers between the groups preconditioned with 10,20 , and $50 \mathrm{mM} \mathrm{H}_{2} \mathrm{O}_{2}$ for $1 \mathrm{~h}$ with recovery for $0 \mathrm{~h}$ before damage and the damage group $(\mathrm{P}>0.05)$, whereas the group preconditioned with $100 \mathrm{mM} \mathrm{H}_{2} \mathrm{O}_{2}$ for $1 \mathrm{~h}$ with recovery for $0 \mathrm{~h}$ before damage had a significantly reduced number of cells compared to the damage group $(\mathrm{P}<0.05$; Table 8$)$.

\begin{tabular}{|c|c|c|c|c|}
\hline \multirow[t]{2}{*}{ Groups } & \multirow[t]{2}{*}{ Control group } & \multicolumn{3}{|c|}{ Concentration of $\mathrm{H}_{2} \mathrm{O}_{2}$ injury } \\
\hline & & $700 \mathrm{mM}$ & $800 \mathrm{mM}$ & $900 \mathrm{mM}$ \\
\hline Without $\mathrm{H}_{2} \mathrm{O}_{2}$ precondition group & $7.200 \pm 0.326$ & $4.200 \pm 0.371$ & $3.800 \pm 0.447$ & $3.300 \pm 0.411$ \\
\hline $10 \mathrm{mM}$ precondition group & $7.300 \pm 0.326$ & $4.550 \pm 0.371$ & $4.150 \pm 0.379$ & $3.650 \pm 0.379$ \\
\hline $20 \mathrm{mM}$ precondition group & $7.400 \pm 0.285$ & $5.000 \pm 0.530$ & $4.550 \pm 0.481$ & $4.000 \pm 0.500$ \\
\hline $50 \mathrm{mM}$ precondition group & $7.050 \pm 0.371$ & $5.650 \pm 0.487$ & $5.150 \pm 0.518$ & $4.550 \pm 0.481$ \\
\hline $100 \mathrm{mM}$ precondition group & $6.900 \pm 0.379$ & $6.200 \pm 0.481$ & $5.650 \pm 0.487$ & $5.000 \pm 0.500$ \\
\hline
\end{tabular}




\begin{tabular}{|c|c|c|c|c|}
\hline \multirow[t]{2}{*}{ Groups } & \multirow[t]{2}{*}{ Control group } & \multicolumn{3}{|c|}{ Concentration of $\mathrm{H}_{2} \mathrm{O}_{2}$ injury } \\
\hline & & $700 \mathrm{mM}$ & $800 \mathrm{mM}$ & $900 \mathrm{mM}$ \\
\hline Without $\mathrm{H}_{2} \mathrm{O}_{2}$ precondition group & $8.200 \pm 0.326$ & $5.000 \pm 0.395$ & $4.500 \pm 0.395$ & $4.000 \pm 0.395$ \\
\hline $10 \mathrm{mM}$ precondition group & $8.300 \pm 0.326$ & $5.150 \pm 0.418$ & $4.650 \pm 0.379$ & $4.150 \pm 0.379$ \\
\hline $20 \mathrm{mM}$ precondition group & $8.400 \pm 0.285$ & $5.300 \pm 0.481$ & $4.800 \pm 0.481$ & $4.300 \pm 0.481$ \\
\hline $50 \mathrm{mM}$ precondition group & $8.050 \pm 0.371$ & $5.600 \pm 0.518$ & $5.050 \pm 0.542$ & $4.500 \pm 0.530$ \\
\hline $100 \mathrm{mM}$ precondition group & $7.900 \pm 0.418$ & $5.900 \pm 0.487$ & $5.300 \pm 0.481$ & $4.700 \pm 0.570$ \\
\hline
\end{tabular}

\begin{tabular}{|c|c|c|c|c|}
\hline \multirow[t]{2}{*}{ Groups } & \multirow[t]{2}{*}{ Control group } & \multicolumn{3}{|c|}{ Concentration of $\mathrm{H}_{2} \mathrm{O}_{2}$ injury } \\
\hline & & $700 \mathrm{mM}$ & $800 \mathrm{mM}$ & $900 \mathrm{mM}$ \\
\hline Without $\mathrm{H}_{2} \mathrm{O}_{2}$ precondition group & $5.700 \pm 0.326$ & $2.600 \pm 0.418$ & $2.100 \pm 0.379$ & $1.600 \pm 0.379$ \\
\hline $10 \mathrm{mM}$ precondition group & $5.800 \pm 0.326$ & $2.500 \pm 0.395$ & $2.000 \pm 0.395$ & $1.500 \pm 0.395$ \\
\hline $20 \mathrm{mM}$ precondition group & $5.900 \pm 0.335$ & $2.400 \pm 0.454$ & $1.900 \pm 0.518$ & $1.400 \pm 0.487$ \\
\hline $50 \mathrm{mM}$ precondition group & $5.550 \pm 0.371$ & $2.150 \pm 0.518$ & $1.700 \pm 0.481$ & $1.250 \pm 0.468$ \\
\hline $100 \mathrm{mM}$ precondition group & $5.400 \pm 0.379$ & $1.800 \pm 0.481$ & $1.400 \pm 0.518$ & $1.000 \pm 0.468$ \\
\hline
\end{tabular}

\section{DISCUSSION}

Based on their various advantages, the use of hUC-MSCs has yielded good results in the treatment of cardiovascular diseases (Wu et al., 2007; Latifpour et al., 2011). Although the treatment of MSCs has progressed in recent years, their effects of ischemia, hypoxia, invasion of inflammatory cells, and other factors in damaged zones can lead to oxidative stress. Excessive reactive oxygen species (ROS) production can result in damage to MSC activity, thus reducing their survival rate in the damage zone, which greatly limits their applications (Toma et al., 2002). Studies have shown that many pathological processes of cardiovascular diseases result in the production of excessive ROS (Kleikers et al., 2012; Liu et al., 2013), which can result in both reversible and irreversible damage to hUC-MSCs, therefore reducing their therapeutic effects.

$\mathrm{H}_{2} \mathrm{O}_{2}$ is one of the most important ROS, and can damage cells in a variety of ways (Cooke et al., 2003; Birben et al., 2012), but can also participate in the survival mechanism against cell damage, mediating an adaptive protective effect of oxidative stress pretreatment (Sharma and Singh, 2001). In this study, we conducted experiments to evaluate the protective effect of short-term pretreatment of low concentration $\mathrm{H}_{2} \mathrm{O}_{2}$ in hUC-MSCs against damage caused by high-concentration $\mathrm{H}_{2} \mathrm{O}_{2}$ for a long time. The results of this study will provide a theoretical basis for improving the survival rate and efficacy of MSCs after transplantation.

HUC-MSC damage by $\mathrm{H}_{2} \mathrm{O}_{2}$ was related to the $\mathrm{H}_{2} \mathrm{O}_{2}$ concentration and duration of action; when the duration of action was short and the $\mathrm{H}_{2} \mathrm{O}_{2}$ concentration was low, the cells did not appear to be damaged, which was related to the cells' own antioxidant mechanisms, whereas when the $\mathrm{H}_{2} \mathrm{O}_{2}$ concentration and duration of action increased, the antioxidation mechanisms of the cells could not implement effective protection. Overdose of $\mathrm{H}_{2} \mathrm{O}_{2}$ can cause cell damage and even necrosis (Pugnaloni et al., 2004). However, after pretreatment of cells with a low concentration of $\mathrm{H}_{2} \mathrm{O}_{2}$ for a short time, the cells can mobilize an internal protective compensatory mechanism to improve their tolerance to longer periods of high-concentration $\mathrm{H}_{2} \mathrm{O}_{2}$ damage. 
This study confirmed that the pretreatment of cells with $\mathrm{H}_{2} \mathrm{O}_{2}$ could produce a protective effect to improve cell oxidation tolerance and weaken the effects of $\mathrm{H}_{2} \mathrm{O}_{2}$ on cell damage; however, there are two conditions of the protective effect after pretreatment. The first condition is pretreatment at an appropriate intensity, and the other is pretreatment at an appropriate interval from high-concentration exposure (Han et al., 2001). If the pretreatment is of insufficient strength, it will not produce a protective effect, whereas if the intensity is too high, it will lead to cell damage and necrosis. Similarly, if the interval is too short after pretreatment, a protective effect will not be produced, whereas if the interval is too long, the protective effect will be weakened.

In this study, we first isolated, cultivated, purified, and identified hUC-MSCs, and then constructed the cell growth curve. Once cells were determined to be at the logarithmic growth phase, the $\mathrm{H}_{2} \mathrm{O}_{2}$ pretreatment, and damage program was optimized, and finally, the $\mathrm{H}_{2} \mathrm{O}_{2}$ pretreatment and damage tests were conducted. The results showed that with respect to cell morphology, the cell metabolic rate, or the number of cells, low-concentration $\mathrm{H}_{2} \mathrm{O}_{2}$ pretreatment over a short-time period significantly improved the tolerance of cells to damage induced by high-concentration $\mathrm{H}_{2} \mathrm{O}_{2}$ exposure over a long period. Furthermore, increasing the $\mathrm{H}_{2} \mathrm{O}_{2}$ concentration pretreatment resulted in increased tolerance. In addition, when the pretreatment interval was $0 \mathrm{~h}$, the cells did not show any tolerance, whereas when the interval was extended to $12 \mathrm{~h}$, a tolerance effect was observed; however, further extending the interval to $24 \mathrm{~h}$ resulted in weakening of the tolerance effect. These results demonstrated that preconditioning hUC-MSCs with $\mathrm{H}_{2} \mathrm{O}_{2}$ could produce a protective effect that is related to the $\mathrm{H}_{2} \mathrm{O}_{2}$ pretreatment intensity and the pretreatment time interval.

Pretreatment of $\mathrm{H}_{2} \mathrm{O}_{2}$ on hUC-MSCs can produce adaptive protection, that is to say, that the use of "non-lethal" stress pretreatment can mobilize the cell's internal protectioncompensatory mechanisms, which protects cells or mitigates more serious damage caused by further exposure (Prass et al., 2003). The adaptive protective effect demonstrated in this study was most likely associated with the following factors: 1) the synthetic molecular chaperones promoting protein synthesis and repair in order to restore the normal function of cells (Riksen et al., 2004), 2) elevating the levels of intracellular antioxidant enzymes to fight the abundance of oxygen-free radicals (Arthur et al., 2004), 3) enhancing the transcription and expression of the iNOS and COX genes, thereby regulating the normal physiological functions of the cells to resist external stress (Yu et al., 2012), 4) increasing the expression of anti-apoptotic protein Bcl-2 to inhibit the activation of Caspase-3, which reduces cell apoptosis induced by high $\mathrm{H}_{2} \mathrm{O}_{2}$ concentrations (Angeloni et al., 2011), 5) activating a variety of cellular signal transduction pathways and jointly controlling apoptosis (Vigneron et al., 2011), and 6) increasing cell cytokine synthesis, thus improving cell exogenous stimulus resistance (Pera et al., 2004).

In the present study, we found that short-term low-concentration $\mathrm{H}_{2} \mathrm{O}_{2}$ pretreatment on hUC-MSCs generated a protective effect to improve tolerance to high-concentration $\mathrm{H}_{2} \mathrm{O}_{2}$ exposure and long-term damage tolerance. This effect was related to the pretreatment intensity and preprocessing time interval, but its specific mechanism was not studied in detail. Therefore, there is a need for more in-depth studies and more systematic explorations on the specific process underlying this protection, as well as the various factors involved.

\section{ACKNOWLEDGMENTS}

Research supported by the Henan Province Major Scientific and Technological Projects (\#122101310500). 


\section{REFERENCES}

Angeloni C, Motori E, Fabbri D, Malaguti M, et al. (2011). $\mathrm{H}_{2} \mathrm{O}_{2}$ preconditioning modulates phase II enzymes through $\mathrm{p} 38$ MAPK and PI3K/Akt activation. Am. J. Physiol. Heart Circ. Physiol. 300: H2196-H2205.

Arthur PG, Lim SC, Meloni BP, Munns SE, et al. (2004). The protective effect of hypoxic preconditioning on cortical neuronal cultures is associated with increases in the activity of several antioxidant enzymes. Brain Res. 1017: 146154.

Birben E, Sahiner UM, Sackesen C, Erzurum S, et al. (2012). Oxidative stress and antioxidant defense. World Allergy Organ. J. 5: 9-19.

Cooke MS, Evans MD, Dizdaroglu M and Lunec J (2003). Oxidative DNA damage: mechanisms, mutation, and disease. FASEB J. 17: 1195-1214.

Fong CY, Subramanian A, Biswas A, Gauthaman K, et al. (2010). Derivation efficiency, cell proliferation, freeze-thaw survival, stem-cell properties and differentiation of human Wharton's jelly stem cells. Reprod. Biomed. Online 21: 391-401.

Han H, Wang H, Long H, Nattel S, et al. (2001). Oxidative preconditioning and apoptosis in L-cells. Roles of protein kinase B and mitogen-activated protein kinases. J. Biol. Chem. 276: 26357-26364.

Kleikers PW, Wingler K, Hermans JJ, Diebold I, et al. (2012). NADPH oxidases as a source of oxidative stress and molecular target in ischemia/reperfusion injury. J. Mol. Med. 90: 1391-1406.

Latifpour M, Nematollahi-Mahani SN, Deilamy M, Azimzadeh BS, et al. (2011). Improvement in cardiac function following transplantation of human umbilical cord matrix-derived mesenchymal cells. Cardiology 120: 9-18.

Li S, Deng Y, Feng J and Ye W (2009). Oxidative preconditioning promotes bone marrow mesenchymal stem cells migration and prevents apoptosis. Cell Biol. Int. 33: 411-418.

Liu M, Gu L, Sulkin MS, Liu H, et al. (2013). Mitochondrial dysfunction causing cardiac sodium channel downregulation in cardiomyopathy. J. Mol. Cell. Cardiol. 54: 25-34.

Pera J, Zawadzka M, Kaminska B and Szczudlik A (2004). Influence of chemical and ischemic preconditioning on cytokine expression after focal brain ischemia. J. Neurosci. Res. 78: 132-140.

Prass K, Scharff A, Ruscher K, Lowl D, et al. (2003). Hypoxia-induced stroke tolerance in the mouse is mediated by erythropoietin. Stroke 34: 1981-1986.

Pugnaloni A, Giantomassi F, Armeni T, Serresi M, et al. (2004). In vitro $\mathrm{H}_{2} \mathrm{O}_{2}$ stress and patterns of mitochondrial damage in the NCTC 2544 continuous cell line - a morphologic and morphometric study. Cell. Mol. Biol. 50 Online Pub: OL517-OL526.

Riksen NP, Smits P and Rongen GA (2004). Ischaemic preconditioning: from molecular characterisation to clinical application - part I. Neth. J. Med. 62: 353-363.

Sharma A and Singh M (2001). Protein kinase C activation and cardioprotective effect of preconditioning with oxidative stress in isolated rat heart. Mol. Cell. Biochem. 219: 1-6.

Taghizadeh RR, Cetrulo KJ and Cetrulo CL (2011). Wharton's Jelly stem cells: future clinical applications. Placenta 32 (Suppl 4): S311-S315.

Toma C, Pittenger MF, Cahill KS, Byrne BJ, et al. (2002). Human mesenchymal stem cells differentiate to a cardiomyocyte phenotype in the adult murine heart. Circulation 105: 93-98.

Vigneron F, Dos Santos P, Lemoine S, Bonnet M, et al. (2011). GSK-3 $\beta$ at the crossroads in the signalling of heart preconditioning: implication of mTOR and Wnt pathways. Cardiovasc. Res. 90: 49-56.

Wu KH, Yang SG, Zhou B, Du WT, et al. (2007). Human umbilical cord derived stem cells for the injured heart. Med. Hypotheses 68: 94-97.

Yu H, Liu Z, Zhou H, Dai W, et al. (2012). JAK-STAT pathway modulates the roles of iNOS and COX-2 in the cytoprotection of early phase of hydrogen peroxide preconditioning against apoptosis induced by oxidative stress. Neurosci. Lett. 529: 166-171. 